\title{
Об особенностях рекомбинации в предварительно засвеченных при повышенной температуре высокоомных пленках a-Si:H
}

\author{
Курова И.А., Ормонт Н.Н.
}

Московский государственный университет им. М.В. Ломоносова, 119992, Москва, Ленинские горы

DOI 10.34077/Semicond2019-331

Исследовались изменения фотоэлектрических свойств нелегированных высокоомных пленок а$\mathrm{Si}: H$ под влиянием освещения разной интенсивности при температурах выше комнатных (Т>400K). Повышенные температуры позволяли измерять медленные при комнатных температурах изменения этих свойств. Исследовались пленки в а-Si:H, выращенные методом плазмохимического осаждения, как после их отжига, так и после их изохронной предварительной засветки белым светом с разной интенсивностью Q. В результате проведенных измерений температурных зависимостей темновой проводимости $\left(\sigma_{d}\right)$ и фотопроводимости $\left(\sigma_{p h}\right)$, а также зависимости фотопроводимости от интенсивности освещения пленок $\mathrm{W}$ было установлено:

1. Величина $\sigma_{d}$ исследованных пленок увеличивается с увеличением интенсивности предварительно засветки Q а $E_{\sigma}$ - термическая энергия активации $\sigma_{d}(T)$-уменьшается.

2. Зависимость $\sigma_{p h}$ исследованных пленок от интенсивности их освещения $\mathrm{W}$ изменяется с увеличением интенсивности их предварительной засветки Q. А именно, величина параметра $\gamma=\frac{d\left(\log \sigma_{p h}\right)}{d(\log W)}$, характеризующая эту зависимость, уменьшается с ростом Q от 0.94 до 0.67 .

Обнаруженные изменения $\sigma_{d}$ и $E_{\sigma}$ указывают на увеличение энергии Ферми с увеличением интенсивности предварительной засветки Q. Так, при $\mathrm{T}=425 \mathrm{~K}\left(E_{C}-F_{0}\right)$ в исследованных пленках изменялось от 0.68 эВ до 0.63 эВ. Уменьшение $\gamma$ указывает на более сильное уменьшение времени жизни электронов с увеличением интенсивности предварительной засветки пленок $\mathrm{Q}$

Подобные изменения $\sigma_{d}, E_{\sigma} \sigma_{p h}$ и $\gamma$ наблюдались в предварительно засвеченных при повышенных температурах легированных фосфором пленках а-Si:H и объяснялись увеличением энергии Ферми вследствие роста степени легирования при засветке пленок. Это, в свою очередь, обуславливало образование дополнительного канала рекомбинации - бимолекулярной рекомбинации на электронных состояниях хвоста зоны проводимости [1].

Эту же модель можно применить и для объяснения результатов данной работы. Однако остается открытым вопрос о природе увеличения энергии Ферми в засвеченных нелегиро ванных пленках. Ранее нами было предположено, что это смещение уровня Ферми может быть обусловлено образованием донорных дефектов типа центровой связи водорода, образующих электронный уровень в верхней половине запрещенной зоны a-Si:H [2,3]. В данной работе указывается также на возможность объяснения обнаруженных аномальных фотоиндуцированных при повышенных температурах изменений фотоэлектрических свойств пленок a-Si:H наличием неконтролируемой примеси кислорода.

[1] R. Bube and Dl. Redfield, J. Appl. Phys., 66(7), 3074 (1989).

[2] R. Kaunavis J. Appl. Phys., 97, 02377 (2005).

[3] И.А. Курова, Н.Н. Ормонт, ФТП, 47, № 6, 757 (2013) 